\title{
12. Cilvēkkapitāls un tautas attīstība
}

\author{
Silvija Kristapsone
}

\section{levads}

Mūsdienu izpratnē jēdziens "ilgtspējīga attīstība" radās 80. gados kā atbilde uz aizvien pieaugošo ražošanu, proti, nepieciešamību līdzsvarot sociālo un ekonomisko progresu ar vides nozīmīgumu un Zemes dabas resursu pārvaldīšanu. Ilgtspējīgas attīstības pamatideja aicina apmierināt tagadējās paaudzes vajadzības, līdzsvarojot sabiedrības labklājības, vides un ekonomiskās attīstības intereses, vienlaikus nodrošinot vides prasību ievērošanu un dabas daudzveidības saglabāšanos, lai nemazinātu nākamo paaudžu vajadzību apmierināšanas iespējas (Latvijas Republikas Saeima, 2010). "Latvijas ilgtspējīgas attīstības stratēgija līdz 2030. gadam” jeb projekts "Latvija 2030" piedāvā indikatorus tautas attīstības novērtēšanai piecu kapitālu skatījumā: cilvēkkapitāls (cilvēku izglītība, veselība, labklājība un ražīgums); ekonomiskais kapitāls (t. sk. vieta, telpa); dabas/vides kapitāls (parastie dabas resursi, vide un ainavas kvalitāte); sociālais kapitāls (cilvēku sociālās saites, sociālo institūtu funkcionēšanas kapacitāte, sociālās organizācijas spēks); kultūras kapitāls (bāzes vērtības (mantojums) un ideju/simbolu radītspēja) (Latvijas Republikas Saeima, 2010).

\section{Tautas attīstība}

ANO pirmais globālais ziñojums par tautas attīstību (angl. Human Development Report) tika publicēts 1990. gadā, un kopš tā laika jēdziens "tautas attīstība" (human development) tiek plaši izmantots. Arī Latvijas attīstība tiek mērìta un salīdzināta ANO Industriālās attīstības organizācijas Tautas attīstības indeksa skalā (44. vieta 188 valstu starpā 2015. gadā) (UNDP, 2016).

Tautas attīstība ir komplekss jēdziens, ko mēra ne tikai ar ekonomiskiem rādītājiem, bet arī ar citiem cilvēka dzīves jomu radītājiem. No 1995. līdz 2017. gadam Latvijā iznākuši trīspadsmit pārskati par tautas attīstību, kuros pētìti sabiedrībai svarīgi jautājumi (LU SZF, 2017).

Tautas attīstības koncepcija sāka veidoties 80. gadu beigās un 90. gadu sākumā, attīstoties idejai par cilvēku dzīves kvalitātes uzlabošanu kā attīstības mērkị, ko realizē, panākot ekonomisko izaugsmi un vienlaikus mainoties 
cilvēka pamatvajadzību pieejai dzīves kvalitātes definīcijā. Tautas attīstība tiek saistīta ar cilvēka cienīgas dzìves veidošanu kvalitatīvā un ilgtspējīgā vidē. Tā ir jauna pieeja labklājībai, kuras centrā ir cilvēks un kur ekonomiskā izaugsme tiek uztverta nevis kā pašmērkis, bet tikai kā līdzeklis cilvēka labklājības sasniegšanai. Līdz ar to tautas attīstību definē kā cilvēka spēju uzlabošanu vai cilvēku izvēles iespēju paplašināšanu (Paula, 2008). Tautas attīstības pamatmērḳis ir radīt veicinošu vidi, lai cilvēki varētu baudīt garu, veselīgu un radošu mūžu. Tautas attīstības un tās ilgtspējas indikatori kḷuvuši par galvenajiem rādītājiem valstu savstarpējā salīdzināšanā.

\section{Cilvēkkapitāls un to raksturojošie rādītāji}

Cilvēkkapitāla vērtību raksturo tā zināšanu, spēju un talantu bāze, izmantošana un produktivitāte. Investīcijas cilvēkkapitālā ir izglìtība, veselības aprūpe, profesionālā sagatavotība un citas aktivitātes, kas padara cilvēkus ekonomiski ražīgākus un emocionāli bagātākus. Cilvēku skaitam samazinoties un sabiedrībai novecojot, būtiski ir saglabāt Latvijas cilvēkkapitāla bāzes vērtību un palielināt tā produktivitāti.

Cilvēkkapitāls ir ne tikai cilvēka spējas, bet arī valsts, uzṇēmumu un paša cilvēka investīcijas šajā kapitālā, lai cilvēks varētu sevi piedāvāt kā augstvērtīgu preci darba tirgū. Aizejot no darba, cilvēks pañem līdzi savu potenciālu - zināšanas un prasmes, rezultātā zaudētājs ir darba devējs, bet plašākā nozīmē arī sabiedrība, jo pastāv darbaspēka geogrāfiskā migrācija starpvalstu līmenī. Jēdziens "cilvēkkapitāls" tiek lietots investīciju kontekstā, ar ieguldījumiem darbinieku izaugsmē, attīstībā un darbības pilnveidošanā izprotot ieguldījumus uzñēmuma pamatkapitālā un novērtējot investīciju atdevi, kas parādās uzṇēmuma darbības rezultātos (Armstrong, 2006). Šajā sakarībā nenoliedzami cilvēkkapitāla raksturotāji ir sabiedrības izglītîbas rādītāji sasaistē ar attiecīgajā ekonomiskajā un sociālajā vidē pieprasītajām zināšanām un prasmēm. Tieši sabiedrības izglîtības pieaugums nodrošina tehnolog̣isko zināšanu progresu, kas ir valsts ekonomiskās izaugsmes pamatā (Becker, 2002). Ja cilvēkkapitāls nav spēcīgs jaunradē, netiek kāpināts valsts radošais kapitāls un netiek attīstītas spējas radìt jauninājumus. Sasaistot terminu "tautas attīstība" un "cilvēkkapitāls" skaidrojumus, var teikt, ka tautas attīstība ir cilvēkkapitāla palielināšanās un tā realizācijas iespēju paplašināšanās (LU SZF, 2007).

Pārresoru koordinācijas centra sagatavotais izdevums "Indikatori 2015. gadā. Latvijas ilgtspējīgas attīstības stratēǵija līdz 2030. gadam. Nacionālais attīstības plāns 2014.-2020. gadam. Uzraudzības ziņojuma pielikums" sniedz norādes, ar kādiem rādìtājiem var novērtēt tautas attīstību. Līdzās stratēégiskiem indikatoriem minēti tādi rādītāji kā iedzīvotāju vispārējais izglītības līmenis, dalība pieaugušo izglîtībā, augstāko izglîtību ieguvušo īpatsvars (Pārresoru, 2015). 
Tautas attīstību un cilvēkkapitālu raksturojošo rādītāju pamatā primāri ir iedzīvotāji - to skaits un vecumstruktūra. Iedzīvotāju skaits Latvijā kopš pagājuša gadsimta 80. gadu beigām samazinās negatīvā dabiskā migrācijas pieauguma rezultātā.

Līdzās iedzīvotāju skaita samazinājumam notikušas izmaiņas Latvijas iedzīvotāju vecumstruktūrā. Krasākās izmaiņas vērojamas divās vecumgrupās: 0-14 gadi un 65 un vairāk gadu. Kopš 1990. gada pirmajā vecumgrupā iedzīvotāju ìpatsvars samazinājies no $21,4 \%$ līdz 15,2\%, bet otrajā pieaudzis no $11,8 \%$ lìdz 19,6\% 2015. gadā. Kopš 1993. gada pensijas vecuma iedzìvotāju ìpatsvars ir lielāks par bērnu un pusaudžu īpatsvaru. Tas nozīmē, ka nākotnē būs mazāks darbspējas vecuma iedzīvotāju skaits un demogrāfiskās slodzes līmenis pieaugs (CSP, 2016a). Prognozes liecina, ka jau 2040. gadā šis īpatsvars pārsniegs 25\% un 2060. gadā pietuvosies 30\% (Eurostat, 2017a).

Iedzīvotāju vecumstruktūras vēlamās izmaiṇas nākotnē nenoliedzami būtu 0-64 gadus vecu iedzīvotāju pieaugošs īpatsvars, un to varētu nodrošināt dzimstības palielināšanās un emigrācijas samazināšanās, kā arī remigrācija. Latvijas un citu ES valstu iedzīvotāju vecumstruktūras prognozes ir līdzīgas, par ko liecina darbspējas vecumu pārsniegušo iedzīvotāju skaita uz 100 darbspējas vecuma iedzīvotājiem pieaugums, un tas Latvijā ir no 41,9 (2020. gadā) līdz 50,9 (2060. gadā) (Eurostat, 2017a).

Iedzīvotāju skaits un vecumstruktūra nosaka cilvēkkapitālu raksturojošā rādītāja - iedzīvotāju izglītības līmeņa - situācijas raksturojumu šobrīd un nākotnē. Ar terminu “izglītība” saprot gan zināšanu apgūšanu, gan arī šì procesa rezultātu. Mūsdienās izglītība parasti nozīmē valsts izstrādātu izglītības saturu un oficiālas, valsts akreditētas, savstarpēji hierarhiski saistītas izglītības iestādes, kuras kopā veido izglītības sistēmu. Parasti tiek nodalīta formālā un neformālā izglītība. Latvijā Izglītības likumā ir noteikts, ka formālā izglītība ir "sistēma, kas ietver pamatizglītības, vidējās izglītības un augstākās izglītības pakāpes, kuru programmu apguvi apliecina valsts atzīts izglītības vai profesionālās kvalifikācijas dokuments, kā arī izglītības un profesionālās kvalifikācijas dokuments" (Izglītības likums, 1998). Neformālā izglītība ir ārpus formālās izglītības organizēta izglītojoša darbība, kas atbilst interesēm un pieprasījumam. Dažādās izglītības sistēmās ir sastopami dažādi faktori, kas tiek izmantoti, lai raksturotu formālo izglītību. Tomēr parasti izglītība tiek raksturota pēc izglìtības pakāpes, izglītības veida un izglītības ieguves formas. Lai salīdzinātu atški irīgas izglītības sistēmas, tiek izmantota Starptautiskā standarta izglītības klasifikācija (The International Standard Classification of Education (ISCED)), kas izšķir deviņus izglītības līmeṇus (ISCED, 1997). Latvijā saskaṇā ar šīs klasifikācijas lietojumu izglītību iedala šādos līmen,os: pirmsskolas izglītība (0 līmenis), pamatizglītība (1-2 līmenis), vidējā izglītība (3-4 līmenis) un augstākā izglītība (5-8 līmenis). Pēc izglītības veidiem nodala vispārējo izglītību, profesionālo izglītību un akadēmisko izglītību (Noteikumi, 2017). Paralēli šiem izglītības 
dalījumiem tiek izmantoti jēdzieni "mūžizglìtība", kas paredz indivīda spēju izglītoties visa mūža garumā, paaugstinot vai mainot savu kvalifikāciju vai iegūstot savām interesēm atbilstošu izglîtîbu; "alternatīvā izglìtība"; "interešu izglìtîba", kurā tiek ietverta izglìtība, kas apmierina individuālās intereses un vajadzības; "speciālā izglîtība"; "publiskā izglīīiba"; "masu izglīîiba" u. c. Pieaugušo izglïtība ir 25-64 gadu vecu personu daudzveidīgs izglìtošanas process, kas nodrošina personas attīstību un konkurētspēju darba tirgū (CSP, 2017).

Cilvēkkapitālu vislabāk raksturo augstāku izglītības pakāpi ieguvušo cilvēku skaits un mūžizglītības rādītāji. Iedzīvotāju skaitam Latvijā samazinoties, kopumā visos izglìtîbas līmeņos samazinās arī izglìtojamo skaits. Tā 2015./2016. mācību gada sākumā kopējais izglìtojamo skaits ir 400,0 tūkst. cilvēku, kas, salīdzinot ar 2010./2011. gadu, samazinājies par 9,8\% (CSP, 2016b). Vidējās izglīîibas (10.-12. klase) grupā izglītojamo skaits samazinājies par $31,2 \%$, un tas skaidrojams ar dzimstības kritumu 90. gadu otrajā pusē. Samazinājies arī izglìtojamo skaits augstākās izglìtības (5.-7. līmenis) un doktorantūras (8. lìmenis) grupā - attiecīgi par 19,2\% un 4,5\%.

2015./2016. mācību gadā mācības neturpināja 4,5\% pamatskolu beigušo (2010. gadā - 5,3\%) un 32,8\% vidusskolu beigušo (2010. gadā - 36,9\%). Šo rādītāju samazinājums vērtējams pozitīvi. Situāciju augstākajā izglīīīā, ko iespējams salīdzināt arī ar citu valstu situāciju, raksturo studējošo skaits uz 10000 iedzīvotāju, un 2015./2016. mācību gadā tie ir 428 studenti salīdzinājumā 501 studentu uz 10000 iedzīvotāju 2010./2011. mācību gadā (CSP, 2016b). Studējošo intensitātes rādītāja kritumu var skaidrot ar studiju maksas pieaugumu, globālās ekonomiskās krīzes radītajām sekām un ar iespējām studēt citās valstīs. Augstāko izglìtību ieguvušo cilvēku īpatsvars nodalītajās vecumgrupās Latvijā pārsniedz ES 28 dalībvalstu vidējo līmeni - Latvija pēc augstāko izglìtību ieguvušo īpatsvara 25-54 gadu vecumgrupā atrodas 13. vietā, bet 55-74 gadu vecumgrupā - 11. vietā ES valstu vidū (12.1. tabula). Tie ir pagājušā gadsimta 40.-50. gados dzimušie iedzīvotāji, kuri ieguva augstāko izglìtību lielākoties vēl padomju laikā. Pēc 2016. gada 1. ceturkšņa datiem, Latvijā bija nodarbināti 28,2 tūkst. cilvēku vecumā no 65 līdz 74 gadiem. Tie ir 3,25\% no visiem nodarbinātajiem iedzīvotājiem.

12.1. tabula. ledzīvotāji pēc izglītības līmeṇa atseviškiās vecumgrupās ES un Latvijā 2016. gadā, \%

\begin{tabular}{|c|c|c|c|c|c|c|c|}
\hline \multicolumn{5}{|c|}{$25-54$ gadi } & \multicolumn{3}{|c|}{$55-74$ gadi } \\
\hline Valsts & $\begin{array}{l}\text { Pamat- } \\
\text { izglitîba }\end{array}$ & $\begin{array}{c}\text { Vidējā } \\
\text { izglïtība }\end{array}$ & $\begin{array}{c}\text { Augstākā } \\
\text { izglītība }\end{array}$ & Valsts & $\begin{array}{c}\text { Pamat- } \\
\text { izglitīiba }\end{array}$ & $\begin{array}{c}\text { Vidējā } \\
\text { izglïtība }\end{array}$ & $\begin{array}{c}\text { Augstākā } \\
\text { izglītīiba }\end{array}$ \\
\hline ES 28 & 20,5 & 46,2 & 33,4 & ES 28 & 36,3 & 43,1 & 20,6 \\
\hline Latvija & 9,7 & 54,8 & 35,5 & Latvija & 13,4 & 62,0 & 24,6 \\
\hline
\end{tabular}

Avots: veidojusi autore pēc Eurostat datiem (2017). 
Cilvēkkapitāla novērtējumā galvenā nozīme ir 25-54 gadu vecumgrupas izglìtības līmenim, un Latvijā šajā vecumgrupā vidējo un augstāko izglìtību ieguvušo īpatsvars pārsniedz ES valstu vidējo līmeni. Vidējo izglītību ieguvušie ir tā mērķauditorija, kura būtu jāieinteresē un jāstimulē iegūt augtāku izglītības pakāpi. Lai arī Latvijā pamatizglītību ieguvušo īpatsvars 25-54 gadu vecumgrupā ir salīdzinoši mazāks nekā daudzās citās Eiropas valstīs šajā pašā vecumgrupā, tomēr te ir iespējas formālajā izglītībā paaugstināt vienas daḷas iedzīvotāju izglìtības līmeni par kādu pakāpi vai arī piedāvāt profesionālo apmācību mūžizglītības programmās. Protams, mērķauditorija ir jaunāka gadagājuma cilvēki. Tie, kuru vecums sliecas uz mūža otru pusi, visticamāk, vairs neredz nedz iespējas, nedz motivāciju savā dzīvē ko mainìt.

Noskaidrojot korelatīvās sakarības starp izglītības rādītājiem dažādās vecumgrupās un IKP uz vienu iedzīvotāju ES valstīs, iegūti šādi rezultāti (12.2. tabula). Statistiski nozīmīgas negatīvas korelācijas $\left(n=28, r_{\text {kritiskais }}=0,374\right.$, $p=0,05$ ) ar IKP veido 20-24 gadus vecu sieviešu grupas (ar pamatizglītību) īpatsvars $(-0,381)$ un 25-54 gadus vecu iedzīvotāju grupas (ar vidējo izglītību) ìpatsvars $(-0,377)$.

Negatīvas korelācijas, kaut arī tās nav statistiski nozīmīgas, uzrāda visas tādu iedzìvotāju grupas, kuriem ir tikai pamatizglītība. Konstatētais, pēc autores domām, skaidrojams ar to, ka zemas kvalifikācijas un zema atalgojuma darbs, ko veic iedzīvotāji, kas ieguvuši pamatizglītību un vidējo izglītību, pašreizējā ekonomiskajā situācijā drīzāk ir IKP pieaugumu bremzējošs faktors. Ne velti šāda izglītības līmeņa ekonomiski aktīvie iedzīvotāji parasti ir Nodarbinātības valsts dienesta reǵistrētie klienti.

12.2. tabula. ledzīvotāju izglīiības pakāpes ieguves īpatsvara un IKP Pīrsona korelācijas koeficienti 2014. gad̄̄

\begin{tabular}{lc}
\hline \multicolumn{1}{c}{ ledzīvotāju izglītības kategorija } & Korelācijas koeficients \\
\hline 30-34 gadi, augstākā izglīīiba (vīrieši) & 0,631 \\
25-54 gadi, augstākā izglītība (kopā) & 0,588 \\
55-74 gadi, augtākā izglītība (kopā) & 0,444 \\
30-34 gadi, augstākā izglītība (sievietes) & 0,312 \\
55-74 gadi, vidējā izglītība (kopā) & $-0,162$ \\
55-74 gadi, pamatizglītība (kopā) & $-0,026$ \\
25-54 gadi, pamatizglītība (kopā) & $-0,023$ \\
20-24 gadi, pamatizglītība (vīrieši) & $-0,288$ \\
20-24 gadi, pamatizglītība (kopā) & $-0,335$ \\
25-54 gadi, vidējā izglītība (kopā) & $-0,377$ \\
20-24 gadi, pamatizglītība (sievietes) & $-0,381$ \\
\hline
\end{tabular}

Avots: autores aprēkini. 
Visaugstāko pozitīvo korelāciju ar IKP uz vienu iedzīvotāju uzrāda tieši 30-34 gadus vecu vīriešu ar augstāko izglìtību īpatsvars $(0,631)$. Sievietēm šajā grupā minētā korelācija ir ar divreiz mazāku ciešuma pakāpi $(0,312)$. Tas saistāms ar dzimuma atšķirībām sabiedrībā, t. i., sievietes vairāk sevi velta gimenei, ierobežo savus karjeras plānus, tādēḷ viņas saṇem zemāku samaksu par vienādu darbu.

Līdzīgu pozitīvu, statistiski nozīmīgu korelāciju ar IKP uzrāda 25-54 gadus vecu iedzīvotāju grupas (ar augstāko izglìtību) īpatsvars un 55-74 gadus vecu iedzìvotāju grupas (ar augstāko izglītîbu) ìpatsvars. Tas lauj secināt par iedzīvotāju ar augstāko izglîtību nozīmi IKP veidošanā: jo lielāks ir augstāko izglītību ieguvušo īpatsvars iedzīvotāju sastāvā, jo lielāka ir saražotā IKP vērtība uz vienu iedzīvotāju valstī. Tas nozīmē, ka viens no galvenajiem ilgtspējīgas tautas attīstības uzdevumiem ir augstākās izglìtības apguves veicināšana, un tas jau tiek darìts. "Latvijas ilgtspējīgas attīstības stratēgijā līdz 2030. gadam" augstākās izglìīibas jautājumi ir cieši saistīti ar cilvēkkapitāla attīstību un produktivitātes kāpinājumu. Cilvēkkapitāla attīstības konteksts un negatīvās demogrāfiskās attīstības prognozes ir noteikušas vienlīdzīgu piekḷuvi visiem izglìtības līmeñiem un tālākizglìtības veicināšanai. Analizējot, kādu īpatsvaru veido ES valstu iedzīvotāji, kam ir augstākā izglītība un kas ir 30-34 gadu vecumgrupā, jāsecina, ka Latvijā 2016. gadā 30-34 gadu vecumā augstāko izglītību ieguvuši 42,8\% šādu iedzīvotāju, pārsniedzot ES vidējo līmeni (Eurostat, 2017b). Nodalot pēc dzimumiem, jāsecina, ka Latvijas sievietes vecumā no 30 līdz 34 gadiem 2016. gadā ir septītās izglìtotākās Eiropas Savienībā, uzrādot šajā vecumgrupā 56,1\% (Eurostat, 2017c), un kopš 2007. gada tas ir pieaudzis 1,8 reizes. Visām ES valstīm ir raksturīgs, ka vīriešiem ir zemāks augstākās izglìtîbas līmenis. Latvijā tādu 30-34 gadus vecu vīriešu īpatsvars, kuriem ir augstākā izglītîba, 2016. gadā bija 30,1\% un 17. vieta ES valstu vidū (Eurostat, 2017b). Tomēr, salīdzinot ar 2007. gadu, tas pieaudzis 1,6 reizes. Latvijai izvirzīto mērḳi - 2030. gadā panākt, ka augstāko izglītību ieguvušo īpatsvars vecumgrupā no 30 līdz 34 gadiem ir lielāks par 40\% (Latvijas Republikas Saeima, 2010), - Latvija jau bija sasniegusi 2015. gadā.

\section{Kopsavilkums}

Tautas attīstība nozīmē cilvēkkapitāla palielināšanos un tā realizācijas iespēju paplašināšanos. Tautas attīstības novērtēšanai līdzās tādiem stratēgiskiem indikatoriem kā, piemēram, iedzīvotāju skaits, vecumstruktūra, IKP, izmanto citus rādītājus: iedzìvotāju vispārējais izglìtības līmenis, dalība pieaugušo izglīiībā, augstāko izglītību ieguvušo ìpatsvars. Iedzìvotāju skaitam Latvijā samazinoties, kopumā visos izglītības līmeņos samazinās arī izglìtojamo skaits. Cilvēkkapitāla novērtējumā galvenā nozīme ir 25-54 gadu vecumgrupas izglìtības līmenim, un Latvijā šajā vecumgrupā vidējo un augstāko izglìtību 
ieguvušo īpatsvars pārsniedz ES valstu vidējo līmeni. Īpaši augsti rādītāji sasniegti 30-34 gadu vecumgrupā. Vidējo izglītību ieguvušie ir tā mērķauditorija, kura būtu jāieinteresē un jāstimulē iegūt augtāku izglītības pakāpi. Lai arī Latvijā pamatizglītību ieguvušo īpatsvars 25-54 gadu vecumgrupā ir salīdzinoši mazāks nekā daudzās citās Eiropas valstīs šajā pašā vecumgrupā, tomēr te ir iespējas formālajā izglītībā paaugstināt vienas daḷas iedzīvotāju izglītības līmeni par kādu pakāpi vai arī piedāvāt profesionālo apmācību mūžizglītības programmās.

\section{Literatūra un avoti}

Armstrong, M. (2006) Handbook of Human Resource Management Practice (10 ${ }^{\text {th }}$ Edition). Kogan Page, Limited.

Becker, G. S. (2002) Human capital [http://www.econlib.org/library/Enc/HumanCapital. html (10.07.2016.)].

CSP (2016a) Demogrāfija 2016. Statistisko datu krājums [https://www.csb.gov.lv/sites/default/ files/publication/2017-03/Nr\%2011\%20Demografija\%202016\%20\%2816_00\%29\%20LV_ EN.pdf (2016.18.07.)].

CSP (2016b) Latvijas statistikas gadagrāmata [https://www.csb.gov.lv/sites/default/files/ publication/2017-06/Nr\%2001_Latvijas_statistikas_gadagramata_2016_Statistical\%20 Yearbook\%20of\%20Latvia_\%2816_00\%29_LV_EN.pdf (04.07.2017.)].

CSP (2017) Metadati. Iedzīvotāji un sociālie procesi. Pieaugušo izglītība [http://www.csb. gov.lv/statistikas-temas/metodologija/pieauguso-izglitiba-37200.html (11.06.2017.)].

Eurostat (2017a) Database [http://ec.europa.eu/eurostat/data/database?p_p_id=NavTreeport letprod_WAR_NavTreeportletprod_INSTANCE_nPqeVbPXRmWQ\&p_p_lifecycle =0\&p_p_ state $=$ normal\&p_p_mode $=$ view\&p_p_col_id $=$ column-2\&p_p_col_count $=1 \quad(11.06 .2016)$.$] .$

Eurostat (2017b) Population by Educational Attainment Level, Sex and Age (\%) - Main Indicators [edat_lfse_03] [http://ec.europa.eu/eurostat/statistics-explained/index.php/Educational_attainment_statistics (04.07.2017.)].

ISCED (1997) International Standard Classification of Education ISCED 1997 [http://www. unesco.org/education/information/nfsunesco/doc/isced_1997.htm (11.06.2016.)].

Izglìtības likums (1998) [http://likumi.lv/doc.php?id=50759 (12.06.2016.)].

Latvijas Republikas Saeima (2010) Latvijas ilgtspējīgas attīstības stratēǵija līdz 2030. gadam, 2010. gada jūnijs [http://www.pkc.gov.lv/images/LV2030/Latvija_2030.pdf (2017.17.01.)].

LU SZF (2007) Latvija. Pārskats par tautas attistību 2006/2007. Cilvēkkapitāls: mans zelts ir mana tauta? Galv. red. Zobena, A. Rīga: LU Sociālo un politisko pētỉjumu institūts, 117 lpp.

LU SZF (2017) Latvija. Pārskats par tautas attīstību 2015/2016 [http://www.szf.lu.lv/petnieciba/petijumipublikacijas/tautas-attistiba-latvija/ (2017.30.06.)].

Ministru kabineta noteikumi Nr. 322 "Noteikumi par Latvijas izglìtības klasifikāciju" (2017) [https://likumi.lv/doc.php?id=291524 (02.08.2017.)].

Paula, L. (2008) Tautas attistïba - ko tas nozimēe? [http://www.lvportals.lv/print.php?id= 170248 (19.06.2016.)].

Pārresoru koordinācijas centrs (2015) Indikatori 2015. gadā: Latvijas ilgtspējīgas attīstības stratēgija līdz 2030. gadam. Nacionālais attīstības plāns 2014.-2020. gadam. Uzraudzības ziņojuma pielikums [http://www.pkc.gov.lv/images/MP_zinojums/MPzinP_07092015_Indikatori.pdf (22.07.2016.)].

UNDP (2016) Human Development Report [http://hdr.undp.org/sites/default/files/2016_human_development_report.pdf (30.06.2017.)]. 